\title{
READING MEDIATION AS A COMMUNICATION RESOURCE FOR HOSPITALIZED CHILDREN: SUPPORT FOR THE HUMANIZATION OF NURSING CARE
}

\author{
Carina Ceribelli ${ }^{1}$ \\ Lucila Castanheira Nascimento ${ }^{2}$ \\ Soraya Maria Romano Pacífico ${ }^{3}$ \\ Regina Aparecida Garcia de Lima ${ }^{4}$
}

Ceribelli C, Nascimento LC, Pacífico SMR, Lima RAG. Reading mediation as a communication resource for hospitalized children: support for the humanization of nursing care. Rev Latino-am Enfermagem 2009 janeirofevereiro; $17(1): 81-87$

The Live Library in Hospitals Project is a strategy adopted by several health institutions for the purpose of providing hospitalized children and adolescents the reading mediation of infant-juvenile stories through professionals and volunteers capable of this function. This study aimed to find out to what extent the reading of stories strategy proposed by this project in hospitals can be a communication resource to use with hospitalized children. In order to do that, empirical data collection was carried out through the use of semi structured interviews with the reader and children above the age of seven years and observation of reading sections. The qualitative data analysis was doing it and it was verified that the reading mediation favors the dialogs and relationships; contribute for the expansion of the diagnostic and therapeutic and development processes of children, relatives and health professionals.

DESCRIPTORS: child, hospitalized; bibliotherapy; pediatric nursing; humanization of assistance

\section{LA MEDIACIÓN DE LA LECTURA COMO RECURSO DE COMUNICACIÓN CON NIÑOS HOSPITALIZADOS}

El Proyecto Biblioteca Viva en Hospitales es una estrategia adoptada por diversas instituciones de salud con el objetivo de llevar al niño y al adolescente hospitalizados a la mediación de la lectura de historias infantejuveniles, por intermedio de profesionales y voluntarios capacitados para esa función. El objetivo de este trabajo es aprender en que medida la estrategia de la mediación de historias, propuesta por lo Proyecto Biblioteca Viva en Hospitales, puede ser un recurso de comunicación con el niño hospitalizado. Para esto, la recolección de datos empíricos fue realizada mediante una entrevista semiestructurada con mediadores y niños mayores de siete años y observando las sesiones de mediación de lectura. Se realizó un análisis cualitativo de los datos y se constató que la mediación de lectura facilita los diálogos y la relación, amplía el proceso diagnóstico y terapéutico y valoriza el proceso de desarrollo de los niños, de los familiares y del equipo de salud.

\section{DESCRIPTORES: niño hospitalizado; biblioterapia; enfermería pediátrica; humanización de la atención}

\section{A MEDIAÇÃO DE LEITURA COMO RECURSO DE COMUNICAÇÃO COM CRIANÇAS HOSPITALIZADAS}

O Projeto Biblioteca Viva em Hospitais é estratégia adotada por diversas instituições de saúde com o objetivo de levar à criança e ao adolescente hospitalizados a mediação de leitura de histórias infanto-juvenis, por intermédio de profissionais e voluntários capacitados para tal função. O objetivo deste trabalho é apreender em que medida a estratégia da mediação de histórias, proposta pelo Projeto Biblioteca Viva em Hospitais, pode ser recurso de comunicação com a criança hospitalizada. Para tanto, a coleta de dados empíricos foi realizada mediante a entrevista semi-estruturada com mediadores e crianças maiores de sete anos e a observação de sessões de mediação de leitura. Procedeu-se à análise qualitativa dos dados e constatou-se que a mediação de leitura facilita os diálogos e o relacionamento, amplia o processo diagnóstico e terapêutico e valoriza o processo de desenvolvimento de crianças, familiares e equipe de saúde.

\section{DESCRITORES: criança hospitalizada; biblioterapia; enfermagem pediátrica; humanização da assistência}

${ }^{1}$ Nurse at Hospital das Clínicas da Faculdade de Medicina de Ribeirão Preto da Universidade de São Paulo, Ribeirão Preto, SP, Brazil, Postgraduate student at Escola de Enfermagem de Ribeirão Preto, da Universidade de São Paulo, Centro Colaborador da OMS para o Desenvolvimento da Pesquisa em Enfermagem, Brazil, e-mail: caceribelli@yahoo.com.br; ${ }^{2}$ RN, Faculty at Escola de Enfermagem de Ribeirão Preto, da Universidade de São Paulo, Centro Colaborador da OMS para o Desenvolvimento da Pesquisa em Enfermagem, Brazil, e-mail: lucila@eerp.usp.br; ${ }^{3}$ Faculty at Faculdade de Filosofia Ciências e Letras de Ribeirão Preto da Universidade de São Paulo, Brazil, e-mail: smrpacifico@ffclrp.usp.br; ${ }^{4}$ RN, Associate Professor at Escola de Enfermagem de Ribeirão Preto, da Universidade de São Paulo, Centro Colaborador da OMS para o Desenvolvimento da Pesquisa em Enfermagem, Brazil, e-mail: limare@eerp.usp.br. 


\section{INTRODUCTION}

$\boldsymbol{I}_{\mathrm{n}}$ Brazil, every year, over one million children are hospitalized for different reasons ${ }^{(1)}$. Several authors ${ }^{(2-3)}$, of different areas of expertise, have discussed the effects that the hospitalization process has on child development, since this experience is potentially traumatic. Besides the changes to their routines and sleep, hygiene and food habits, the children are subject to situations in which they have little or no control. Hospitalization can also trigger the onset of negative feelings like anguish, anxiety, and fear in view of this unknown and threatening situation ${ }^{(4)}$. In small children, the worst suffering is caused by the separation from their mother. Hospitalization can also cause disorders regarding affectivity, limited abstract thinking, and cognitive difficulties ${ }^{(2)}$.

Making the hospital a pleasant place is one resource to minimize the adverse effects of hospitalization, and this goal can be reached through the humanization of pediatric care. If the goal of care given to hospitalized children is one of comprehensive care ${ }^{(3)}$, it should not be limited to the medication interventions or to rehabilitation techniques.

With a view to increasing and improving the diagnostic and therapeutic process, some strategies used by health institutes, the so-called humanization projects, have undergone evaluations that evidence the improvement in health care quality. The most referred projects include the Live and Let Live Project, Safe Motherhood, Children's Friend Hospital, Humanized Delivery, Kangaroo Mother, Hospital Class, Happiness Doctors and Live Library in Hospitals Project, also known as $\mathrm{PBVH}^{(5)}$.

The Live Library in Hospitals Project was created in 1994 by an institution named Color of the Letter. This institution joins writers, illustrators, and literature professionals who voluntarily seek to disseminate the value of reading. In 1995, the program was incorporated to the actions developed by the Abrinq Foundation for Children and Adolescents' Rights and, by 2002, it had already been implemented in 293 places, including schools, social institutions, day care centers, and socio-educational programs, with 78000 children and adolescents in its communities $^{(6)}$.

In 2000, the Health Ministry of Brazil established a partnership with the Abrinq Foundation to create a specific version of the program to be implemented in public hospitals in Brazil, the Live Library in Hospitals Project ${ }^{(5-6)}$. In May 2001, the Hospital das Clínicas of Faculdade de Medicina de Ribeirão Preto at University of São Paulo implemented the PBVH with support from the Health Ministry, Abrinq Foundation, and Citibank, receiving 300 books, including literature classics, pop-up books, toy-books and educational books, which were appropriate for children of all ages. It also received support material, such as cushions, rugs, carts to move books, and shirts for the mediators (volunteers). The general purpose of the PVH is to provide hospitalized children of all ages with a reading experience of age-appropriate books, through employees and volunteers recruited for this function. The project sets priority on focusing the care on the child or adolescent, allowing them to choose and actively participate in the proposed moment, but it also involves parents and employees, providing experiences and important exchanges from the narratives and the infant-juvenile literature books $^{(5)}$

At first, one nurse, one social worker, and a librarian at the institution were trained, thus forming the project's multidisciplinary group, which, since then, has trained teams consisting of employees, interns and volunteers who tell stories to the hospitalized children and adolescents.

The PBVH has intersection points with Bibliotherapy ${ }^{(8)}$, which is therapy through books, even if the mediators perform the simple task of reading stories, respecting the children and adolescents' choice to listen to them. The children's and adolescents' reactions show evidence of their experience in relation to their disease and care, their acceptance and understanding. This information is relevant to plan comprehensive and humanized care.

Hence, the purpose of this study is to learn to what extent the strategy of mediating infantjuvenile stories, proposed by the Live Library in Hospitals Project, can be a communication resource for hospitalized children.

\section{METHODOLOGICAL APPROACH}

This is a descriptive and exploratory study, ${ }^{(9)}$ and the answers to its inquiries were sought using the qualitative approach, due to the characteristics of the study object and the proposed objective. 
As per the National Health Council Resolution $196 / 96$, the research proposal was submitted to the Research Ethics Committee of the Hospital das Clínicas of Faculdade de Medicina de Ribeirão Preto at University of São Paulo and was subsequently approved.

The chosen study field was the campus unit of Hospital das Clínicas of Faculdade de Medicina de Ribeirão Preto at University São Paulo (HCFMRPUSP). The Pediatric Clinic, located on the $7^{\text {th }}$ floor, has 40 beds and was the place where empirical data were collected. Study participants were 14 children, boys and girls, aged between three and 12 years, and hospitalized in this sector during the first semester of 2006. As for the mediators, nine of those working in the project at the moment of data collection were selected.

The empirical data were collected using two methods, observation and interview. Observation was used to identify the child's and adolescent's degree of participation, how the hospitalization progressed, changes in the child's expression while listening to the story, their acceptance of undergoing procedures during the mediation and the child's reaction when the reading was over and the mediator said goodbye. Semi-structured interviews were also used, and were performed with the mediators and with children older than 7 years. The choice to hold the interview only with children in this age range, that is, above seven years, is due to the fact that they are in the logical thinking phase of development, and are able to verbally communicate their ideas, adding value to their experiences ${ }^{(10)}$.

In the interviews with the mediators, the information sought was how they came to know and became interested in the $\mathrm{PBVH}$, what are the benefits of mediating reading, what feelings they experienced when telling stories and why they felt the PBVH was a tool to communicate with the hospitalized child. With the children, the effort was to find out about what kind of story they prefer, why they enjoy listening to stories, how they feel while listening to them, and what relations they establish between the story (imaginary world) and their life.

Permission from the legal guardians of the children, usually parents, regarding their participation in the study was obtained after explaining about the study objective and the technique used for data collection and, upon their agreement, they were asked to sign the free and informed consent form. The same procedure was carried out with the reading mediators.

To ensure the anonymity of the children participating in the study, their names were replaced with the letters $\mathrm{A}$ to $\mathrm{N}$, followed by their age, and with the letters I (when it concerned the interview) or $O$ (referring to observation). The mediators were identified by numbers from I to IX, also followed by I (for interview) or $\mathrm{O}$ (for observation).

The empirical material produced from the interviews and the observation sessions was typed and organized in separate files, and an analysis was made of the stages determined by the thematic content analysis technique, i.e. pre-analysis, analysis of the expressed and latent feelings, elaboration of the themes, and final analysis(11). The data were grouped according to two themes: stories and the therapeutic and educational possibilities, and communication and story telling.

\section{RESULTS AND DISCUSSION}

When characterizing the participants, it was found that the mediators learned about the Live Library in Hospitals Project through posters, through people who referred the program, and also through the local media. They attended the institution twice a week at the most, for two consecutive hours. The mediators were between 30 and 60 years old, had completed post-secondary studies, were married, and had children. All mediators reported getting personal benefits from mediating reading for the hospitalized children, and also stated being interested in the project due to the need to do something for others. Some of them also had the habit of telling stories to their own children. The dates in which these reading mediators were trained to work on the project ranged between 2002, when the project started in this hospital, to March 2006, when the last training session was performed.

The children were between three and 12 years old; $40 \%$ boys and $60 \%$ girls. Most were hospitalized in order to treat chronic diseases, such as oncohematologic, gastrointestinal, pneumopathic, and chronic renal diseases. The minimum hospitalization time was three weeks, but one child had been living at the institution for five years. They all stated that they liked to listen to music during the hospitalization for several reasons, but some stated that the main reason was learning. 
The stories and the therapeutic and educational possibilities

The therapeutic possibilities of story telling were noticed, although the PBVH story-tellers are not experts in that function, and it is free, non-directed reading. Here, it is supported that reading provides readers or listeners with more than the pleasure from the text; it gives them the possibility of discovering emotional security, the catharsis of internal conflicts, and the feeling of belonging, of love, engagement in action and overcoming difficulties ${ }^{(12)}$.

In this sense, the report from a mediator exemplifies that possibility, below.

It even helps in the procedures. I had an experience in which the nurse came to do a procedure and the child was really shy and wouldn't cooperate at all. I, without knowing about it, entered the room, introduced myself as a mediator, told the child some stories, we talked a little, and, when I left the room, the nurse went in to try again. Later, she told me how important the reading mediation was for that child; it was so good for her that she agreed to the procedure (I, IX).

The children who took part in the study mentioned that reading at the hospital was an opportunity for learning and also a gratifying pastime, as reported below.

Stories teach you. Those that explain things, like that one about the seed [a Bible story 'The seed of truth' [by Patricia Engel Secco], all the boys lied and only one told the truth and you have to tell the truth. So I think that there are stories that teach (I, F-10 years).

The stories are really communicative, we don't think about bad things, we don't just watch television (I, J-11 years).

For children, the hospital is a different, unfamiliar, and often scary environment. Also, separation from the family, due to hospitalization, can cause several emotional traumas, leading to aggressive behaviors like rage and violence, or constant crying followed by anguish and depression, as well as learning difficulties and delays in their development ${ }^{(13)}$.

When using reading as a resource to minimize the stress of hospitalization, it is necessary to consider aspects of infant-juvenile development. For example, pre-schoolers (between three and six years) experience a rapid development of their vocabulary and language skills, and understand their experience by using symbols, including language. School-aged children (between six and eight years) are improving their reading and like to know about concepts and skills, pre-adolescents (between eight and 11 years) like realist fiction and books that describe real life events, since they are learning to make choices and developing personal values, and adolescents (between 12 and 18 years) like novels and fiction, fantasy, or even individual non-assisted readings ${ }^{(6)}$.

For mediators, the stories provide a sense of wellbeing, but are also educational, as observed in the reports.

The PBVH provides wellbeing, happiness, maybe momentarily because I leave and I don't know how they feel after that, but I think it increases. Because I leave that seed in their mind; when I leave and say: think a lot about this story and see what you have learned! Like the educational ones, of not throwing trash on the ground. So I think it provides many benefits for the children because they can take substance from there, good things for their lives (I, III).

In the book 'Cotton Ball' [by Marly Mattos], the child becomes fascinated with the cotton ball, so she wants to go to the hospital to get new bandages and it is blown by the wind. The mediator smiles and says: 'like this cotton that you use here!'So the cotton ball gets dirty and cannot help a person ( $O$, K- 6 years).

Considering other learning fields (affectiveemotional, spiritual, intellectual) it is possible to see the infant and juvenile literary production questioning values and demystifying them. Through different books and authors, children and adolescents can find in them, and with them, the true human values.

Through the language used in fairytales, the child understands some things that, if explained to them too realistically, they would be unable to internalize. Fairytales give positive psychological contributions to the child's internal development, since the "truths" in fairytales, if internalized, serve as the foundation for solving psycho-emotional problems in childhood, adolescence, and adult life. The telling of fairytales triggers and intensifies a series of feelings and experiences in the child, such as compassion, criticism, tension, relief, sadness, happiness, fear, and courage. Reading a fairytale to a child is a form of nurturing their soul and their creative strength to deal with difficult situations, such as disease ${ }^{(14)}$.

Story-tellers report that the act of telling stories is a learning mechanism for the ones listening, and also for the ones telling the story. They report having benefited from the reading mediation, because they learn with it and with the situations experienced in the hospital, as reported below. 
I haven't been in this project for long, but I am learning a lot with them; and they also understand that adults do not always impose things, but can offer some things, too. It isn't a cold thing, you know? It is a human moment, with great empathy (I, V).

These benefits were also observed for the children.

The child chooses the 'Biggest, strongest, fastest' book [by Steve Jenkins]. Showing the animals, the mediator asks if she knows each of them and their names; the child smiles and says some names like lion and giraffe, getting it right. She continues smiling at me and at her mother, always paying attention to the reading and the mediator, who then shows her a jellyfish and a tarantula. For these pictures, the child shows an expression of surprise and curiosity and doesn't answer when asked about the names. So the mother tells her the name of the animals and explains where they live ( $0, \mathrm{M}-3$ years). When this bilateral aspect of the humanization projects is portrayed, which implies that the chosen humanization strategy should benefit those receiving and performing the $\operatorname{action}^{(15)}$, an acknowledgement of this fact is observed in the report of this study's PBVH mediators regarding the benefit for those working with the volunteer story-tellers. Below is an example.

I think the family, the parents and, I believe, even the nurses benefit from reading mediation. The person there listens to the story, and at that moment is transported, leaving the hospital and entering a fantasy. I notice it isn't just the child that feels that way, and I think it is good for me (I, II).

Story-telling is considered a universal message that everyone is capable of understanding, an experience already lived at some point in life. The stories act as food for the soul, awakening one's curiosity and encouraging the search for explanations, and they have the ability to value different alternatives to win challenges ${ }^{(8,14)}$.

It is a fact that reading children's stories, either by children or mediated by the story-tellers, contributes to the process of literacy and reading development during the pre-school and school periods ${ }^{(16)}$. It is the first benefit considered to result from a project like PBVH.

\section{Communication and story-telling}

Reading mediation can also serve as a form of communicating with the hospitalized child. Since it facilitates non-verbal communication, it makes it possible to have a more intuitive relationship. Through fables and fantastic stories, accessible to their level of comprehension, they relieve strong emotions like rage, fear, pain, and suffering ${ }^{(14)}$.

Reading mediators reaffirm this benefit when they reveal that story-telling makes communication with hospitalized children possible or more feasible, and state how much it favors the dialogues between the children and the nursing team, as well as with the multiprofessional team and among other children and their families. The following statement, given by a mediator, is an example.

The child is a little shy with the adult, but with another child they start playing at once, sometimes talking, but with the adult, they feel shy and it [story-telling] is a way to open a little door and gain easier access to them; one talk can also make this opening, but the talk is longer and it takes more time to conquer a child. When you meet them and immediately start a story, you enter their world directly, in the world of imagination. This way they start to open up more and talk a little more with you (I, I).

Health and disease are parts of the same continuum, which can be affected by cultural, biological, individual, and collective factors, as well as by one's behavior, beliefs, attitudes, and values. Educational support is outlined as an element of health care, and communication between the nursing team and the client becomes necessary for it to be successful ${ }^{(13)}$. Based on this perspective, reading mediation plays the role of making communication between the child and the nursing team easier, besides encouraging the patients to talk about their feelings, as shown by the following example.

I liked the story 'The biggest flour in the world' [by José Saramago]. I liked it, but it is very difficult [the child talks about the character that injured his foot]. Because his foot was bleeding and it hurt. Then he fainted (I, D - 8years).

His mother always said that he didn't talk much, that he had always been very quiet, sad because of the problem, and when I arrived I talked to him a lot, and I noticed he liked to listen to the stories, he felt happier with the books! So it was really memorable for me because the mother said he almost didn't open up to her and that he became very introverted because of the treatment, but he opened up to me. I noticed that the stories did him $\operatorname{good}(\mathrm{I}, \mathrm{VI})$.

Studies ${ }^{(5,8,14)}$ show the importance and relevance of the dialogues generated by reading mediation since, through them, it is possible to learn how children experience hospitalization, the treatment and the suffering they go through, in addition to understanding the relationships between the child, the team, and their families. 
Even when they do not speak, the children express their feelings of anxiety, anguish, and fear, including fear of death, through games, drawings and in the stories, and that expression of feeling relieves the stress caused by hospitalization ${ }^{(13,17)}$. Hence, it is advocated herein that reading mediation is a forum for children to express themselves, of placing within a dialogue all the feelings expressed by the characters, figures, and messages contained in the children literature books. The following statement is an example of that.

I liked the 'Ugly duckling' [by Suely Mendes Brazão] ... Because no one liked him! But in the end he was a swan (I, A 10 years).

Analyzing the previous statements, it is possible to see the contributions of story-telling to nursing care, since these children talk about the difficulty experienced by characters that "bleed and feel pain", and the "ugly ducking that no one liked", but that, after all, became a swan. In these words, it is possible to identify the complications of oncohematologic diseases and nephropathies, which cause physical changes, such as hair loss. For nurses, understanding what these patients feel and seeing to their needs, besides their physical well-being, means obtaining elements and the underlying information to improve the quality of the care delivered by the whole health team.

This is true because the hospital is not exclusively a place of pain and suffering. There is always some extra room that should be used to develop pedagogical and recreational activities, since hospitalization should not interrupt the child's development.

\section{FINAL CONSIDERATIONS}

Pediatric nurses have asked themselves if clinical aspects alone are enough to analyze their performance, considering that humanistic and artistic elements could also be a part of teaching, and, therefore, be a part of nursing. From this perspective, nursing care cannot be developed solely based on the knowledge of biologic and social sciences, disregarding arts and humanity ${ }^{(7)}$. In this sense, arts and philosophy are essential for the development of tailored comprehensive care, since it allows for reaching a broader and more accurate knowledge about human nature, the individual and the collective world.

From this presupposition, care to hospitalized children should provide not only the physical aspects of care, but should also consider the emotional and social aspects, such as including appropriate communication and relationship techniques, which can be based on literature, for instance. Reading mediation permits the health team to access, identify, acknowledge and understand what the hospitalized child's true needs are.

Unquestionably, after reading mediation, there is more conversation between patients and the nursing professionals and, indeed, the whole family. In clinical practice, nurses know how relevant effective communication is with patients and between nursing team members, hampering the continuity of care and its effectiveness in care, as well as the relationships, when information is not passed on due to communication failures. Nurses and nursing team members can use transition objects like toys and books to get closer to their pediatric patients, and that possibility is observed in the present study results.

Health care humanization is required to meet the needs of hospitalized patients, especially those with chronic diseases, long treatment, and numerous re-hospitalizations that do not always include having their family around. Reading mediation is a resource to relieve anxiety, desolation, apathy, and suffering in hospitalized children and adolescents, besides the broadness of these actions in nursing in "caring for the caregiver", which is essential to improve patient care quality.

The present results agree with those of previous studies ${ }^{(18-20)}$, which have shown the possibilities of developing new competencies for health care, capable of assigning new meanings to nursing practice, allying technical-scientific and human competence with a view to the humanization of a health care process that considers both patients and health care workers.

\section{REFERENCES}

1. Ministério da Saúde (BR). DATASUS. [on-line]. Brasília: Ministério da Saúde; 2007. [Acessado em 01 set. 2007].
Disponível em: http//www.datasus.org.br.

2. Castro A Neto. As fases turbulentas da hospitalização. Rev Pediatria Moderna 2000; 4(36): 245-7.

3. Lima RAG. Criança hospitalizada: a construção da 
assistência integral. [Tese]. Ribeirão Preto (SP): Escola de Enfermagem de Ribeirão Preto/USP; 1996.

4. Santa Roza E. Um desafio às regras do jogo. In: Santa Roza E, Reis ES, organizadores. Da análise na infância ao infantil na análise. Rio de Janeiro (RJ): Contra Capa; 1997. p. 161-88.

5. Fundação Abring (BR). Biblioteca viva: fazendo histórias com livros e leituras. São Paulo (SP): Fundação Abrinq; 2004.

6. Projeto Biblioteca Viva em Hospitais (PBVH). Formação de multiplicadores: Material de Apoio. São Paulo; 2002.

7. Ceribelli C. A mediação de leitura como recurso de comunicação com crianças e adolescentes hospitalizados: subsídios para a humanização do cuidado de enfermagem. [Dissertação]. Ribeirão Preto (SP): Escola de Enfermagem de Ribeirão Preto /USP; 2007.

8. Caldin CF. A leitura como função terapêutica: Biblioterapia. [on-line]. 2001. [Acessado em 25 set. 2003]. Disponível em: www.encontros-bibli.ufsc.br.

9. Polit DF, Hungler BP. Fundamentos de pesquisa em enfermagem. 3a ed. Porto Alegre (RS): Artes Médicas; 1995. 10. Wong DL. Enfermagem pediátrica: elementos essenciais à intervenção efetiva. 5 ed. Rio de Janeiro (RJ): Guanabara Koogan; 1999.

11. Flick U. Uma introdução à pesquisa qualitativa. 2 ed. Porto Alegre: Bookman; 2004.

12. Fontenele MFS, Pinto VB, Andrade FJM, Dias AP, Moura RMG, Pinto JMB. A biblioterapia no tratamento do câncer infantil. [on-line]. 2006. [Acessado em 05 fev. 2007]. Disponível em http://dici.ibict.br.

13. Vieira MA, Lima RAG. Crianças e adolescentes com doença crônica: convivendo com mudanças. Rev Latino-am Enfermagem 2002; 10(2):23-30.

14. Bettelheim B. A psicanálise dos contos de fadas. 16 ed. Rio de Janeiro (RJ): Paz e Terra; 2002.

15. Deslandes SF. Análise do discurso oficial sobre a humanização da assistência hospitalar. Rev Ciência e Saúde Coletiva 2004 maio-junho; 9(1): 15-7.

16. Bragato Filho P. Pela leitura literária na escola de $1^{\circ} \mathrm{grau}$. São Paulo: Ática; 1995.

17. Morsh DS, Aragão PM. A criança, sua família e o hospital: pensando processos de humanização. In: Deslandes SF, organizadora. Humanização dos cuidados em saúde: conceitos, dilemas e práticas. Rio de Janeiro (RJ): Fiocruz; 2006.

18. Gatti MFZ, Silva MJP. Ambient music in the emergency services: the profissionals' perception. Rev Latino-am Enfermagem 2007; 15(3): 377-83.

19. Pedro ICS, Nascimento LC, Poleti LC, Lima RAG, Mello DF, Luiz FMR. Playing in the waiting room of an infant outpatient clinic from the perspective of children and their companions. Rev Latino-am Enfermagem 2007; 15(2): 290-7.

20. Backes DS, Koerich MS, Erdmann AL. Humanizing care through the valuation of the human being: resignification of values and principles by health professionals. Rev Latino-am Enfermagem 2007; 15(1): 34-41. 